\title{
Dynamic Loading and Unloading of Proteins in Polymeric Stomatocytes: Formation of Enzyme- Loaded Supramolecular Nanomotor
}

Loai K. E. A. Abdelmohsen, Marlies Nijemeisland, Gajanan M. Pawar, Geert-Jan A. Janssen, Roeland J. M. Nolte, Jan C. M. van Hest and Daniela A. Wilson*

Radboud University, Institute for Molecules and Materials, Heyendaalseweg 135, 6525 AJ, Nijmegen, The Netherlands

* Address correspondence to: d.wilson@science.ru.nl (D.A.W)

\section{Table of Contents}

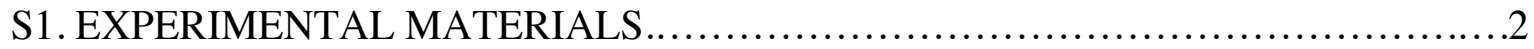

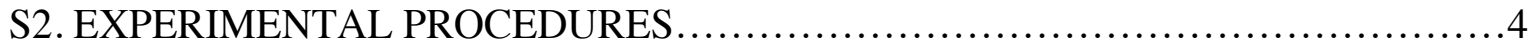

S3. SUPPLEMENTARY FIGURES AND TABLES ................................ 8

S3.1. Reverse dialysis and solvent addition methods for stomatocytes formation.........8

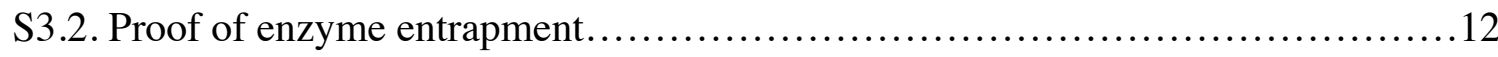

S3.2.1. AFFF-MALS-QUELS ......................................... 12

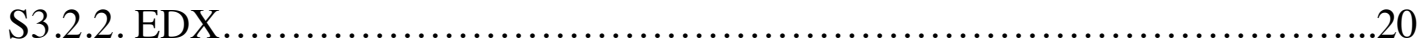

S3.2.3. Incorporation efficiency of enzymes in the stomatocytes determination....22

S3.3. Enzyme driven nanomotors tracking and analysis............................. 24

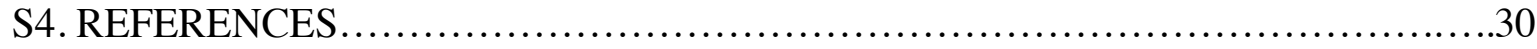




\section{S1. Experimental Materials:}

All chemicals and enzymes were used as received unless otherwise stated. For the block copolymer synthesis, styrene was distilled before the polymerization to remove the inhibitor. Anisole and $N, N, N^{\prime}$, $N$ ', $N$ ''-pentamethyl-diethylenetriamine (PMDETA) were purchased from Sigma Aldrich. Ultra pure MilliQ water obtained from Labconco Water Pro PS purification system (18.2 M $\Omega$ ) was used for the polymersomes self-assembly and their dialysis. Dialysis Membranes MWCO 12,000-14,000 g mol ${ }^{-1}$ Spectra/Por ${ }^{\circledR}$ were used for dialysis during the shape transformation. Ultrafree-MC centrifugal filters 0.22 $\mu \mathrm{m}$ were purchased from Millipore. Sodium Nitrate was purchased from Merck. Catalase from bovine liver (E.C. 1.11.16) lyophilized powder 2000-5000 $\mathrm{U} \mathrm{mg}^{-1}$ was purchased from Sigma Aldrich. Glucose Oxidase (E.C. 1.1.3.4) from Aspergillus niger Type II lyophilized powder $228.25 \mathrm{U} \mathrm{mg}^{-1}$ was purchased from Sigma Aldrich. Peroxidase from horseradish (E.C. 1.11.1.7) Type I, 50-150 U mg-1 solid and Ampliflu $^{\mathrm{TM}}$ Red were purchased from Sigma Aldrich.

Proton nuclear resonance: (HNMR) spectra were recorded on a Varian Inova 400 spectrometer with $\mathrm{CDCl}_{3}$ as a solvent and TMS as internal standard.

Gel permeation chromatography: (GPC) was used to determine the molecular weights of the blockcopolymer. Shimadzu Prominence GPC system equipped with a PL gel $5 \mu \mathrm{m}$ mixed D column (Polymer Laboratories) and differential refractive index and UV (254 nm) detectors were used. THF was used as an

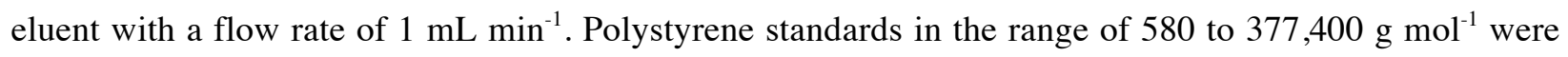
used for calibration.

Transmission electron microscopy: (TEM) experiments were performed on a JEOL 1010 microscope equipped with a CCD camera at an acceleration voltage of $60 \mathrm{kV}$. Samples were prepared by placing $5 \mu \mathrm{L}$ of the solution on a carbon-coated $\mathrm{Cu}$ grid (200 mesh, EM science) and they were allowed to air-dry for at least 24 hours. Processing and analysis of TEM images was performed with ImageJ, a program developed by the NIH and available as public domain software at http://rsbweb.nih.gov/ij/. 
Cryogenic transmission microscopy: The cryogenic transmission electron microscopy (Cryo-TEM) experiments were performed on a JEOL TEM 2100 microscope (JEOL, Japan) and Processed and analysed with ImageJ.

AF4-UV-MALS-Quels: The asymmetric field flow fractionation - UV - Quels (AF4-UV-Quels) experiments were performed on a Wyatt Eclipse AF4 instrument connected to Shimadzu LC-20A Prominence system with Shimadzu CTO20A injector. The AF4 was further connected to the following detectors: a Shimadzu SPD20A UV detector, a Wyatt DAWN HELEOS II light scattering detectors (MALS) installed at different angles angles $\left(12.9^{\circ}, 20.6^{\circ}, 29.6^{\circ}, 37.4^{\circ}, 44.8^{\circ}, 53.0^{\circ}, 61.1^{\circ}, 70.1^{\circ}, 80.1\right.$ ${ }^{\circ}, 90.0^{\circ}, 99.9^{\circ}, 109.9^{\circ}, 120.1^{\circ}, 130.5^{\circ}, 149.1^{\circ}$, and $157.8^{\circ}$ ) using laser operating at $664.5 \mathrm{~nm}$, a Wyatt Optilab Rex refractive index detector and a Quels detector installed at angle of $140.1^{\circ}$. Detectors were normalized using Bovine Serum Albumin and for enzymes molecular weight calculations, dn/dc of 0.1850 was used. The AF4 channel was pre-washed with running solution of $5 \mathrm{mM} \mathrm{NaNO}$, which was also used for the separation. The processing and analysis of the LS data and hydrodynamic radii calculations were performed using Astra 6.1.1. All AFFF separations were performed on AF4 short channel with regenerated cellulose (RC) $10 \mathrm{KDa}$ membrane (Millipore) and spacer of $350 \mu \mathrm{m}$.

Nano-particle tracking analysis: These experiments were performed on a Nanosight LM10HS instrument equipped with an Electron Multiplication Charge Coupled Device (EMCCD) camera. This camera is mounted on an optical microscopic in order to track the light scattered by the injected particles that are present in the focus of the $80 \mu \mathrm{m}$ beam generated by a single mode laser diode with a $60 \mathrm{~mW}$ blue laser illumination $(405 \mathrm{~nm})$. The solution containing polymeric vesicles was adjusted to a concentration between $10^{7}$ and $10^{9}$ particles $\mathrm{mL}^{-1}$. Solutions were injected into the nanosight sample chamber. The chamber has a $0.5 \mathrm{~mL}$ size from which a volume of $120 \times 80 \times 20$ microns was visualized under the microscope. The Brownian motion of the nanoparticles was tracked with 30 frames $\mathrm{s}^{-1}$. NTA 2.2 software was used to track the vesicles and from this, their mean square displacement (MSD) was calculated. The same method of MSD calculation was explained in detail elsewhere. ${ }^{1}$ 
Fluorescent measurements: The fluorescent measurements were performed on a 96- black well FBottom microplates (Greiner Bio-One) on a Berthold TriStar ${ }^{2}$ LB 942 Multidetection Microplate Reader equipped with a $550 \mathrm{~nm}$ excitation filter and a $610 \mathrm{~nm}$ emission filter.

\section{S2. Experimental Procedures:}

Synthesis of poly(ethylene glycol)-polystyrene block copolymer: Amphiphilic block copolymer PEG- $b$-PS was synthesized according to literature procedures using atom-transfer living radical polymerization. ${ }^{2}$ Briefly, to a dry Schlenk tube equipped with a stirring bar, copper bromide (CuBr) (45 $\mathrm{mg}, 0.32 \mathrm{mmol}$ ) was added under argon atmosphere. The Schlenk tube was then sealed with a septum, evacuated for 15 min after which argon was filled back into the flask. PMDETA ( $66 \mu \mathrm{L}, 0.32 \mathrm{mmol})$ was dissolved in $0.5 \mathrm{~mL}$ of anisole and added into the $\mathrm{CuBr}$. The mixture was left stirring for 15 min with argon bubling through the solution for oxygen removal. Subsequently, polyethylene glycol macro initiator (215 $\mathrm{mg}, 0.10 \mathrm{mmol}$ ) was dissolved in $1 \mathrm{~mL}$ of anisole and added into the Schlenk tube. Schlenk tube was inserted in an ice bath, and the solution was degassed for $15 \mathrm{~min}$. Afterwards, distilled styrene (5 ml, 43.6 mmol) was inserted into the Schlenk tube. The mixture was degassed by three freeze thaw cycles and after which, the Schelnk tube was inserted into a preheated $70{ }^{\circ} \mathrm{C}$ oil bath for over night. dichloromethane $\left(\mathrm{CH}_{2} \mathrm{Cl}_{2}\right)(75 \mathrm{~mL})$ was then added into the polymer solution and the organic later was extracted with aqueous $65 \mathrm{mM}$ EDTA solution $(3 \times 150 \mathrm{~mL})$. The aqueous phase was washed with $\mathrm{CH}_{2} \mathrm{Cl}_{2}$ and the organic layers were combined and dried with $\mathrm{MgSO}_{4}$. The solution was then concentrated and the polymer was precipitated in cold $\mathrm{MeOH}$, filtered and dried overnight. The amphiphilic polymer obtained, $\mathrm{PEG}_{44}-b-\mathrm{PS}_{167}$ had am number average molecular weight $\left(\mathrm{M}_{\mathrm{w}}\right)$ of $19,574 \mathrm{gmol}^{-1}$ and a PDI of 1.07.

\section{Preparation of polymersomes for either solvent addition or reverse dialysis methods: Block-}

copolymer $\mathrm{PEG}_{44}-b-\mathrm{PS}_{167}(20 \mathrm{mg})$ was dissolved in $2 \mathrm{~mL}$ of a mixture of distilled THF and dioxane (4:1 $\mathrm{v} / \mathrm{v}$ ) in a $15 \mathrm{~mL}$ vial equipped with a magnetic stirring bar. The vial was capped with a rubber septum followed by the addition of $3 \mathrm{~mL}$ of MilliQ via a syringe pump with a rate of $1 \mathrm{~mL} \mathrm{~h}^{-1}$ while stirring the 
solution vigorously. The resulted cloudy suspension was transferred into a dialysis membrane (SpectraPor, molecular weight cutoff: 12,000-14,000 Da, flat width $25 \mathrm{~mm}$ ), which was prior swollen in MilliQ for about $30 \mathrm{~min}$. The polymersomes were dialyzed against water $(1000 \mathrm{~mL})$ for at least 24 hours.

\section{Stomatocytes formation via the reverse dialysis of polymersomes: Rigid membrane} polymersomes were dialyzed against a mixture of THF : dioxane $4: 1$ and samples were withdrawn from the dialysis bag at different time points. Briefly, a solution of $\mathrm{PEG}_{44}-b-\mathrm{PS}_{167}$ polymersomes $(700 \mu \mathrm{L})$ was placed in a dialysis membrane (SpectraPor, molecular weight cut-off: 12,000-14,000 Da, flat width 10 $\mathrm{mm}$ ), which was swollen in MilliQ for $30 \mathrm{~min}$. The dialysis solution was composed of $150 \mathrm{~mL}$ MilliQ (50\% in volume) and a mixture of $120.0 \mathrm{~mL} \mathrm{THF}$ and $30.0 \mathrm{~mL}$ dioxane $(4: 1 \mathrm{v} / \mathrm{v})$. To monitor the shape transformation by cryogenic transmission microscopy, samples were withdrawn from the dialysis bag through different experiments at $30 \mathrm{~min}, 60 \mathrm{~min}, 90 \mathrm{~min}, 120 \mathrm{~min}, 150 \mathrm{~min}$. and $180 \mathrm{~min}$.

Stomatocytes formation via the solvent addition method: A mixture of THF : dioxane (4:1 v/v) was added via syringe pump $\left(300 \mu \mathrm{L} \mathrm{h}^{-1}\right.$ rate) to rigid polymersomes solution $\left(10 \mathrm{mg} \mathrm{mL}^{-1}\right)$ in five separate vials from which samples were withdrawn at different time points. Briefly, in five separate experiments (vials 1-5), an aqueous polymersome solution based on $\mathrm{PEG}_{44}-b-\mathrm{PS}_{167}$ block copolymer (500 $\mu \mathrm{L}, 10 \mathrm{mg} \mathrm{mL}^{-1}$ ) was transferred into the $5 \mathrm{~mL}$ vials equipped with a magnetic stirring bar. The vials were sealed during the addition while a $0.6 \mathrm{~mm}$ thin needle was placed to release the overpressure resulting from the high solvent vapor pressure, which was expected to affect the process. Subsequently, $150 \mu \mathrm{L}$, $300 \mu \mathrm{L}, 450 \mu \mathrm{L}, 600 \mu \mathrm{L}$, and $700 \mu \mathrm{L}$ respectively of organic solvent mixture (THF and dioxane, 4:1 v/v) were delivered via a syringe pump with a rate of $300 \mu \mathrm{L} \mathrm{h}^{-1}$ in each vial while stirring the solution vigorously $(800 \mathrm{rpm})$. To follow the shape transformation by Cryo TEM, the experiment was stopped at different time intervals after $30 \mathrm{~min}$ (vial 1), $60 \mathrm{~min}$ (vial 2), $90 \mathrm{~min}$ (vial 3), $120 \mathrm{~min}$ (vial 4), and 180 min (vial 5) respectively by quenching the structures in $2 \mathrm{~mL}$ of water. The solution of rigid stomatocytes was then concentrated via centrifugation back to their initial concentration of $10 \mathrm{mgmL}^{-1}$. 
Enzyme encapsulation in stomatocytes: First, a batch of opened stomatocytes (Neck size $103 \pm 9$ $\mathrm{nm}$ ) was prepared following the previous mentioned solvent addition method. It was prepared by addition of $300 \mu \mathrm{L}$ of THF : dioxane $(4: 1 \mathrm{v} / \mathrm{v})$ with a rate of $300 \mu \mathrm{L} \mathrm{h}^{-1}$ into a rigid polymersome solution (500 $\mu \mathrm{L}, 10 \mathrm{mg} \mathrm{mL}^{-1}$ ) in a septum sealed $5 \mathrm{~mL}$ vial equipped with $0.6 \mathrm{~mm}$ needle. The formed stomatocytes were quenched by addition of $2 \mathrm{~mL}$ of water, followed by spin filtration to remove the organic solvent. The spin filtration step was repeated at least 5 times to ensure complete removal of the organic solvent and the final volume was decreased to $500 \mu \mathrm{L}$ to afford a $10 \mathrm{mg} \mathrm{mL}^{-1}$ final concentration of stomatocytes. Subsequently, $6 \mathrm{mg}$ of catalase (in case of catalase filled stomatocytes) or $2 \mathrm{mg}$ of catalase and $6 \mathrm{mg}$ of glucose oxidase (in case of catalase and glucose oxidase motors) were added to the $103 \pm 9$ opening rigid stomatocytes. The solution was left stirring for at least $30 \mathrm{~min}$ followed by addition of $150 \mu \mathrm{L}$ of THF : dioxane $(4: 1 \mathrm{v} / \mathrm{v})$ with a rate of $300 \mu \mathrm{L} \mathrm{h}^{-1}$ in $30 \mathrm{~min}$. Immediately after the solvent addition, the organic solvent and non-encapsulated enzymes were removed via spin filtration and dialysis against $5 \mathrm{mM} \mathrm{NaNO}_{3}$ solution.

Measurement of catalase activity: For catalase activity, a standard curve was prepared from a $10 \mathrm{U}$ $\mathrm{mL}^{-1}$ catalase stock solution to $86 \mu \mathrm{L}$. Concentrations were chosen to obtain a final concentration between 0 to $0.8 \mathrm{U} \mathrm{ml}^{-1}$ in $100 \mu \mathrm{L}$ assay volume. Catalase-containing samples were approximately 1000 times diluted to $86 \mu \mathrm{L}$ in order to obtain concentrations that fall into the standard curve concentrations. To start the reaction $4 \mu \mathrm{L}$ of $500 \mu \mathrm{M} \mathrm{H}_{2} \mathrm{O}_{2}$ was pipetted to every well containing the standard and experimental solutions. After 30 minutes of incubation at room temperature, $20 \mu \mathrm{L}$ of a master mix containing HRP $\left(100 \mu \mathrm{L}\right.$ of $\left.10 \mathrm{U} \mathrm{mL}^{-1}, 8.69 \mathrm{U} \mathrm{mL}^{-1}\right)$ and Ampliflu ${ }^{\mathrm{TM}} \operatorname{Red}(5 \mu \mathrm{L}$ of $20 \mathrm{mM}$ in DMSO, $869.6 \mu \mathrm{M})$ was added to each well. Fluorescence was measured, using excitation at $550 \mathrm{~nm}$ and emission at $590 \mathrm{~nm}$, after 5 minutes of incubation at room temperature. A background correction was made by subtracting the value from the no-catalase control from every sample. 
Measurement of glucose oxidase (GOx) activity: A glucose oxidase standard curve was prepared by dilution of the appropriate amount of the glucose oxidase stock solution to $89.5 \mu \mathrm{L}$, to obtain a final concentration between 0 and $0.4 \mathrm{U} \mathrm{ml}^{-1}$ in $100 \mu \mathrm{L}$ assay volume. Stomatocytes were serially diluted to $89.5 \mu \mathrm{L}$ to determine the optimal amount of sample that falls in the standard curve range.

Standard curve and experimental samples were loaded into individual wells of a microplate. The reaction was started by adding with a multipipet to each well, $11.5 \mu \mathrm{L}$ of a master mix containing D-glucose (10 $\mu \mathrm{L}$ of $1 \mathrm{mM}, 86,9 \mu \mathrm{M}), \operatorname{HRP}\left(100 \mu \mathrm{L}\right.$ of $\left.\left.10 \mathrm{U} \mathrm{ml}^{-1}, 8.69 \mathrm{U} \mathrm{mL}^{-1}\right)\right)$ and Ampliflu ${ }^{\mathrm{rN}} \operatorname{Red}(5 \mu \mathrm{L}$ of $20 \mathrm{mM}$ in DMSO, $869.6 \mu \mathrm{M})$.The progress of the reaction was monitored directly for 10 minutes by measuring the increase in fluorescence emission at $590 \mathrm{~nm}$ after excitation at $550 \mathrm{~nm}$. For each point, the value derived from the negative control was subtracted. 


\section{S3. Supplementary Figures and Tables:}

\section{S3.1. Reverse dialysis and solvent addition methods for stomatocytes formation}

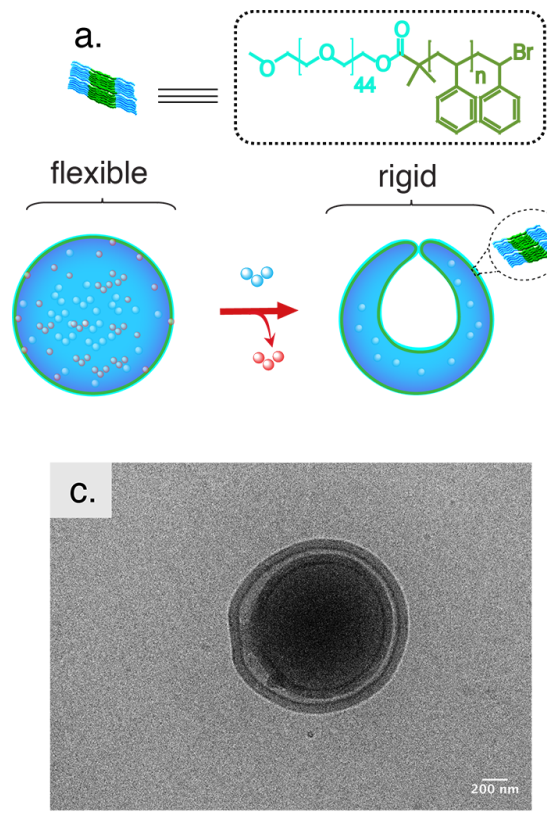

b.

= water $\quad$ organic solvent (THF : Dioxane)
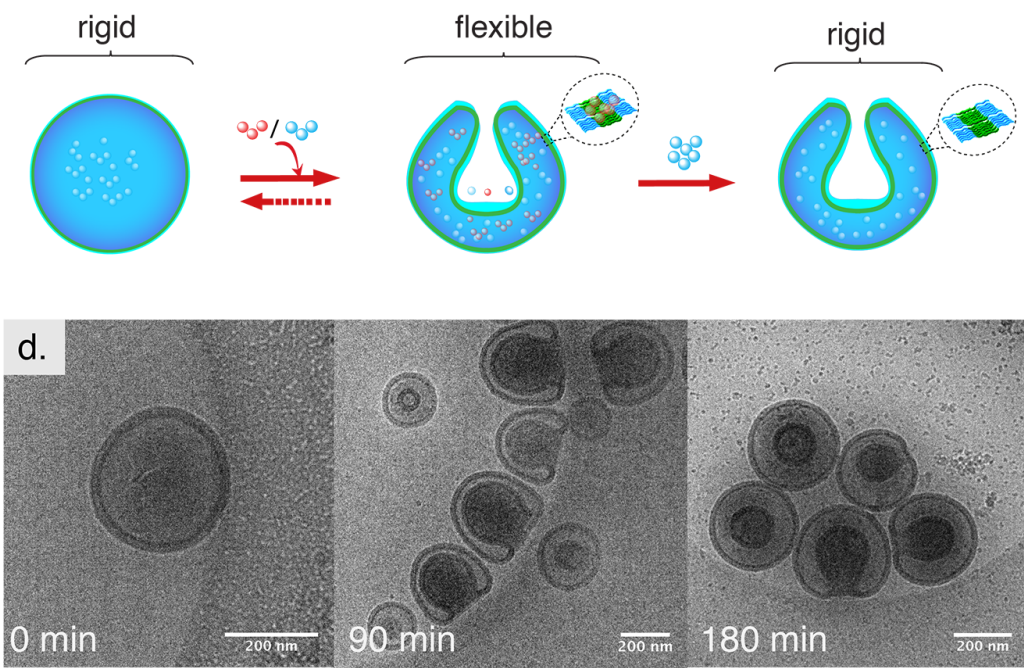

Supplementary Figure 1: Stomatocytes formation via dialysis methods. a. Schematic representation of the shape transformation of polymersomes via the dialysis method where the removal of the organic solvent (red spheres), used to inject the polymer solution into water (blue spheres), induces an osmotic stress over the membrane resulting in the inward folding of the membrane. b. Schematic representation of the shape transformation of polymersomes via the reverse dialysis method where first organic solvent and water is added to promote flexibility of the polymersome membrane after which an osmotic driven shape change into stomatocytes is applied, followed by quenching the structure in water to preserve the morphology. c. Cryo-TEM of stomatocytes obtained via the dialysis method described in (a) d. CryoTEM of the polymersomes and stomatocytes obtained after reverse dialysis in a mixture of water : THF : dioxane (1:0.8:0.2 v/v) as described in (b). Note the decreasing size of the opening after increasing the dialysis time. All scale bars correspond to $200 \mathrm{~nm}$. 

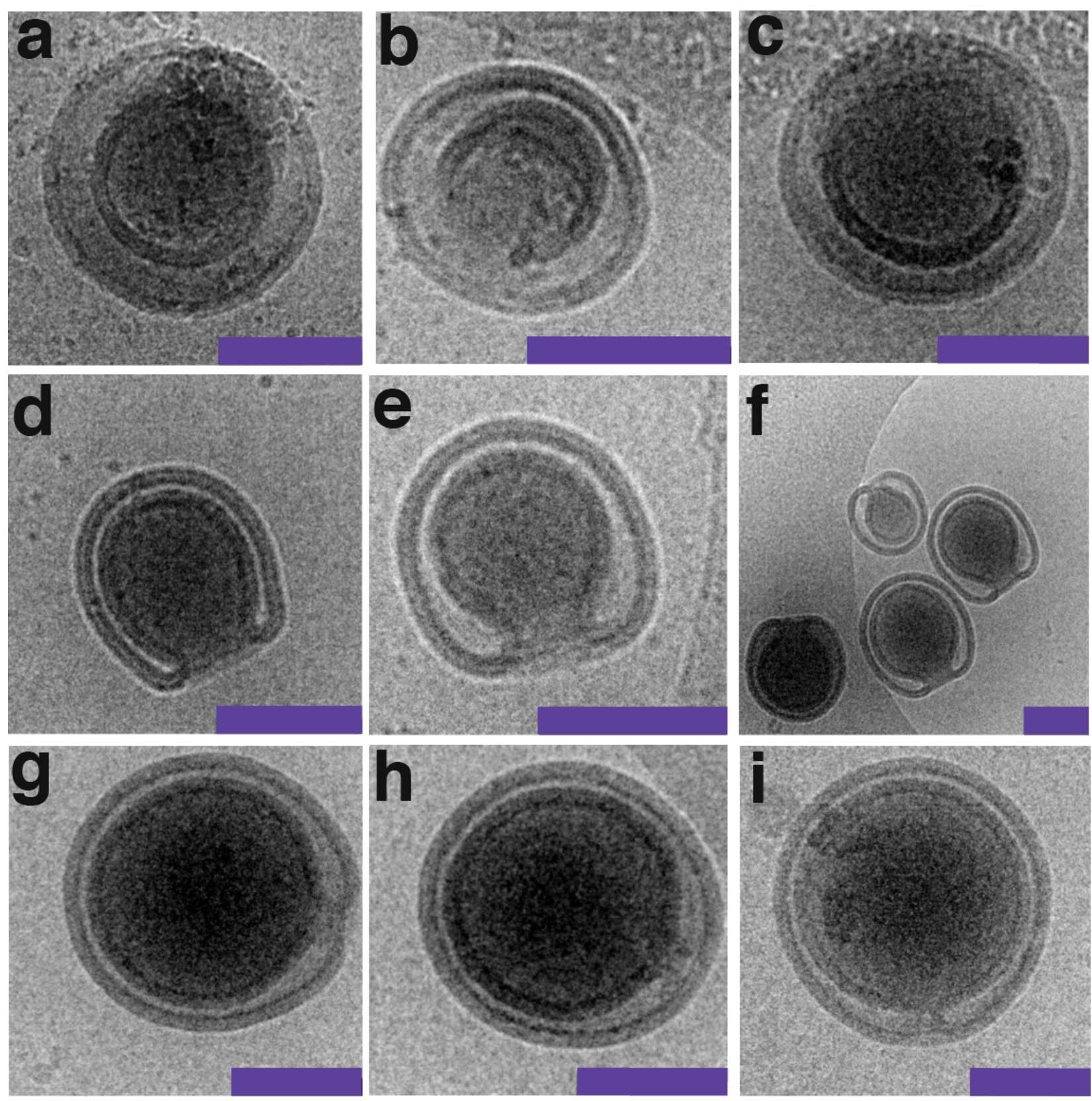

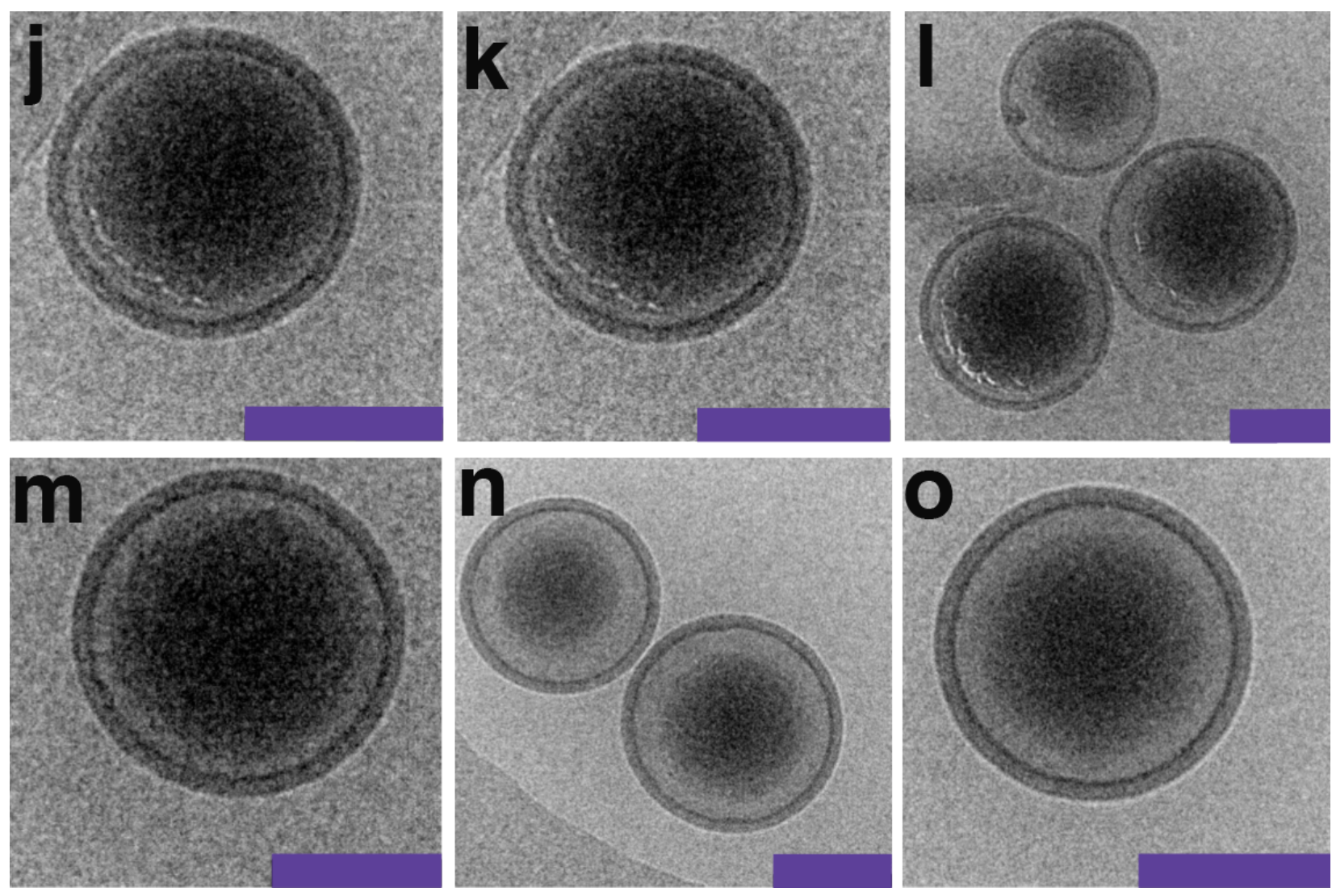

Supplementary Figure 2: Cryo-TEM of the shape transformation of polymersomes into stomatocytes at different time points via the solvent addition method. a, b, c, Cryo-TEM of stomatocytes after shape transformation via solvent addition for $\mathbf{3 0}$ min as obtained. d, e, f, Cryo-TEM of stomatocytes after shape transformation via solvent addition for $60 \mathrm{~min} . \mathbf{g}, \mathbf{h}, \mathbf{i}, \mathbf{C r y o}-\mathbf{T E M}$ of stomatocytes after shape transformation via solvent addition for $\mathbf{9 0} \mathbf{m i n}$. j, k, l, Cryo-TEM of polymersomes after shape transformation via solvent addition for $\mathbf{1 2 0}$ min. $\mathbf{m}$, n, o, Cryo-TEM of polymersomes after shape transformation via solvent addition for $\mathbf{1 8 0} \mathrm{min}$. Scale bar is equal to $200 \mathrm{~nm}$. 

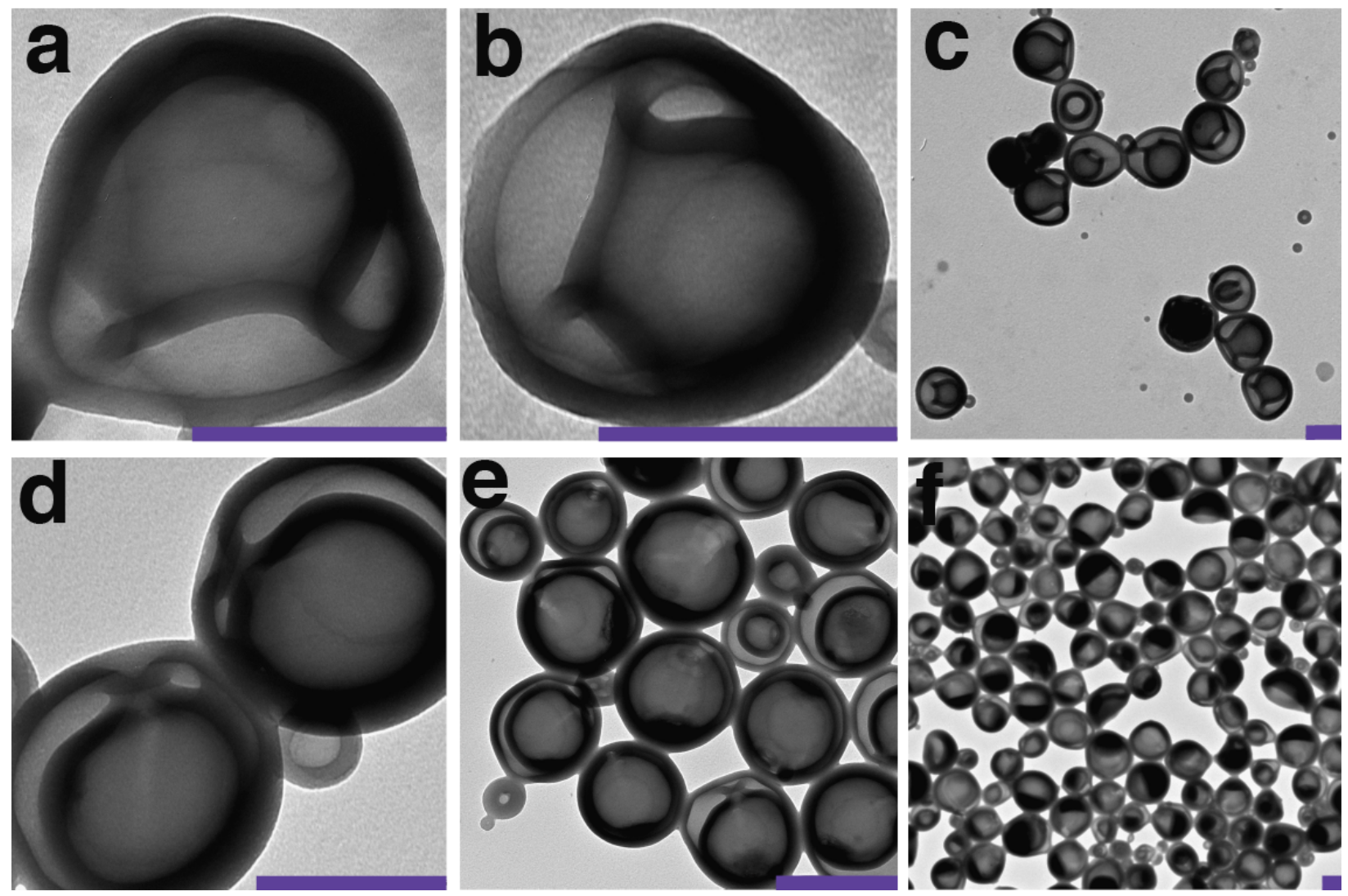

Supplementary Figure 3: (Top a, b, and c) TEM images of rigid stomatocytes formed after addition of $300 \mu \mathrm{L}$ of organic solvent (THF : dioxane, $4: 1 \mathrm{v} / \mathrm{v}$ ) to aqueous polymersomes solution. (Bottom d, e, and f) TEM images of closed rigid stomatocytes encapsulating enzymes. They are formed by mixing the top opened stomatocytes with $6 \mathrm{mg}$ of catalase (in case of catalase filled stomatocytes) or $2 \mathrm{mg}$ of catalase and $6 \mathrm{mg}$ of glucose oxidase (in case of catalase and glucose oxidase motors). 30 min later, $150 \mu \mathrm{L}$ of organic solvent (THF : dioxane, $4: 1 \mathrm{v} / \mathrm{v}$ ) was added into the mixture. Right after $30 \mathrm{~min}$, the formed structures were spin filtered and dialyzed against $5 \mathrm{mM} \mathrm{NaNO}_{3}$ solution. Scale bar is equal to $200 \mathrm{~nm}$. 


\section{S3. 2.Proof of enzymes entrapment}

\section{S3.2.1. AF4-MALS-QUELS}

\begin{tabular}{|l|l|l|l|l|}
\hline $\begin{array}{l}\text { Start } \\
(\mathrm{min})\end{array}$ & End (min) & Mode & Cross flow start $\left(\mathrm{mL} \mathrm{min}^{-1}\right)$ & Cross flow end $\left(\mathrm{mL} \mathrm{min}^{-1}\right)$ \\
\hline 0 & 1 & Elution & 3.00 & 3.00 \\
\hline 1 & 2 & Focus & - & - \\
\hline 2 & 3 & Focus + inject & - & - \\
\hline 3 & 4 & Focus & - & - \\
\hline 4 & 6 & Elution & 3.00 & 1.17 \\
\hline 6 & 8 & Elution & 1.17 & 0.49 \\
\hline 8 & 10 & Elution & 0.49 & 0.24 \\
\hline 10 & 13 & Elution & 0.24 & 0.10 \\
\hline 13 & 30 & Elution & 0.10 & 0.10 \\
\hline 30 & 31 & Elution & 0.00 & 0.00 \\
\hline 31 & 32 & Elution + inject & 0.00 & 0.00 \\
\hline 32 & 37 & Elution & 0.00 & 0.00 \\
\hline
\end{tabular}

Supplementary Table 1 General method for the AFFF separation of stomatocytes from enzymes.

The flow conditions applied for the FFF separation were the following: $1.0 \mathrm{~mL} \mathrm{~min}^{-1}$ detector flow, 1.00 $\mathrm{mL} \min ^{-1}$ focus flow and $0.20 \mathrm{~mL} \mathrm{~min}^{-1}$ injection flow. The same parameters were used earlier for separation of platinum nanoparticles from stomatocytes. ${ }^{3}$

For the control experiments with the enzymes (catalase and/or GOx), $20 \mu \mathrm{L}$ from a $3 \mathrm{mg} \mathrm{mL}^{-1}$ solution in MilliQ was injected into the AFFF short channel. For the stomatocytes control experiments without enzymes, $20 \mu \mathrm{L}$ from a $10 \mathrm{mg} \mathrm{mL}^{-1}$ solution was injected, while for the stomatocyte control experiments mixed with enzymes (catalase and/or GOx), $40 \mu \mathrm{L}$ from a $10 \mathrm{mg} \mathrm{mL}^{-1}$ polymer (PS-PEG) mixed with 3 $\mathrm{mg} \mathrm{mL} \mathrm{L}^{-1}$ enzymes solution was injected into the AFFF short channel. 


\begin{tabular}{|l|l|l|l|l|}
\hline $\begin{array}{l}\text { Start } \\
(\mathrm{min})\end{array}$ & End (min) & Mode & Cross flow start $\left(\mathrm{mL} \mathrm{min}^{-1}\right)$ & Cross flow end $\left(\mathrm{mL} \mathrm{min}^{-1}\right)$ \\
\hline 0 & 2 & Elution & 3.00 & 3.00 \\
\hline 2 & 3 & Focus & - & - \\
\hline 3 & 5 & Focus + inject & - & - \\
\hline 5 & 6 & Focus & - & - \\
\hline 6 & 22 & Elution & 3.00 & 3.00 \\
\hline 22 & 25 & Elution & 0.00 & 0.00 \\
\hline 25 & 28 & Elution+inject & 0.00 & 0.00 \\
\hline
\end{tabular}

Supplementary Table 2 General method for the AFFF elution of enzymes: The flow conditions applied for the elution of enzymes were the following: $0.5 \mathrm{~mL} \mathrm{~min}{ }^{-1}$ detector flow, $1.50 \mathrm{~mL} \mathrm{~min}^{-1}$ focus

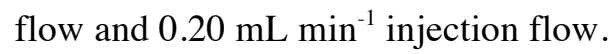




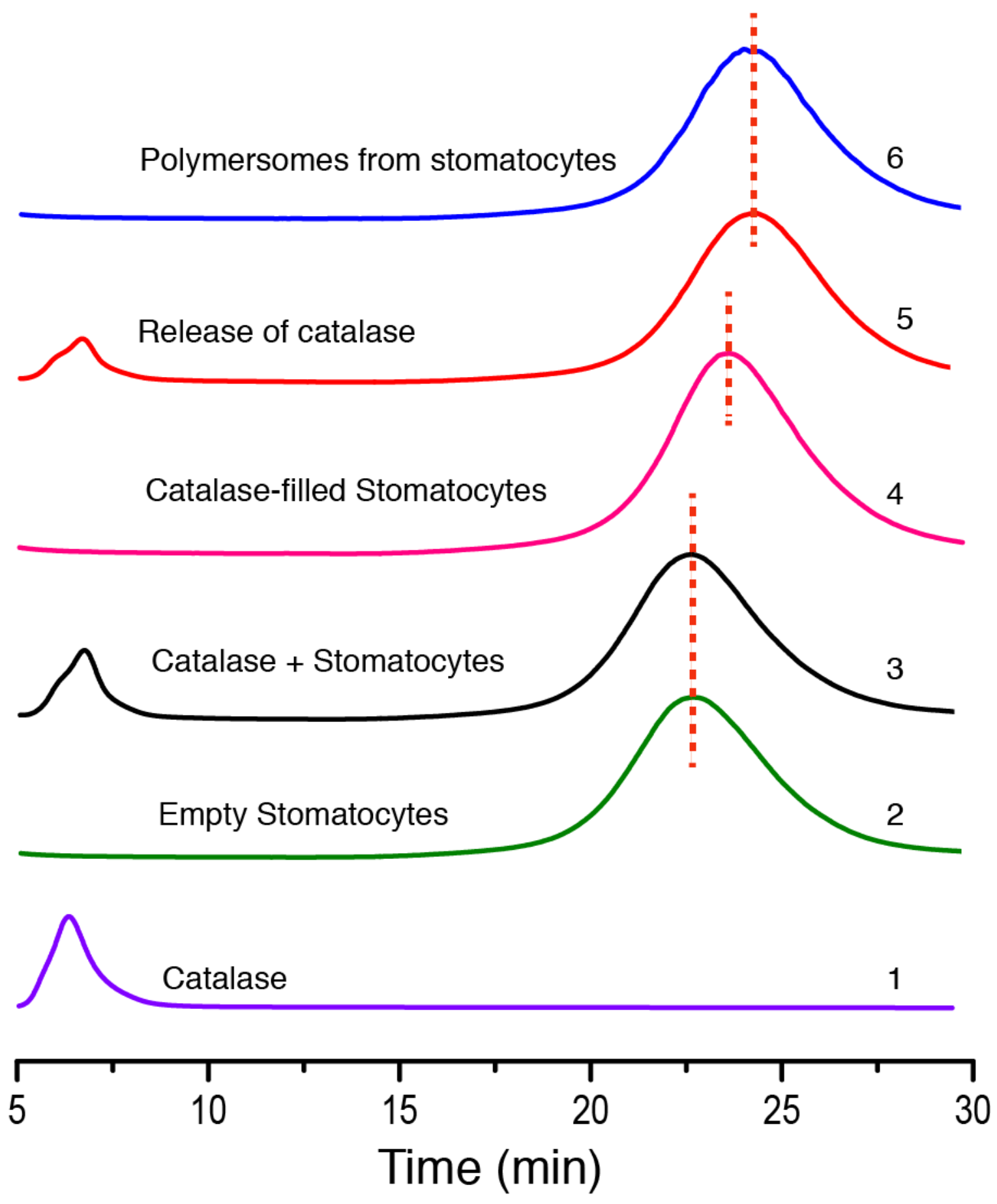

Supplementary Figure 4: Asymmetric field flow field fractionation (AFFF) chromatogram of 1catalase, which was later encapsulated inside the cavity of the stomatocytes. 2- AFFF chromatogram of empty closed stomatocytes (obtained after $90 \mathrm{~min}$ of the solvent addition method). 3- AFFF chromatogram of catalase and stomatocytes mixed together, this experiment was done to check if catalase 
is interacting with the membrane of the stomatocytes. According to this chromatogram, the enzyme does not adhere onto the stomatocytes as both peaks of catalase and the stomatocytes are retained at exactly the same retention time of their controls (1 and 2). 4- AFFF chromatogram of closed stomatocytes encapsulating catalase. Note the chromatogram of the filled stomatocytes shows a slight shift to a later retention times, this can be explained by the fact that the measured hydrodynamic radii of the filled stomatocytes are bigger than the non-filled ones and thus with a lower diffusion coefficient. 5- AFFF chromatogram of polymersomes obtained from empty stomatocytes. Note that the chromatogram shows a shift of the polymersomes peak to later time, this can be explained by the fact the polymersomes are usually bigger than their stomatocytes counter parts. ${ }^{4}$ 6- AFFF chromatogram of the release experiment where the filled stomatocytes were shape transformed into polymersomes and this led into the release of the encapsulated enzymes and thus, retention of the catalase peak. Note that all the measurements were performed on the structures coming out from the same original polymersome batch, as such one polymersomes batch was divided into 4 batches, one of them was shape transformed into opened stomatocytes (obtained after $60 \mathrm{~min}$ of solvent addition) and then closed as stated above and subsequently they were shape transformed into polymersomes. The same procedures were exactly applied on another batch, with catalase being added during the closing step. 

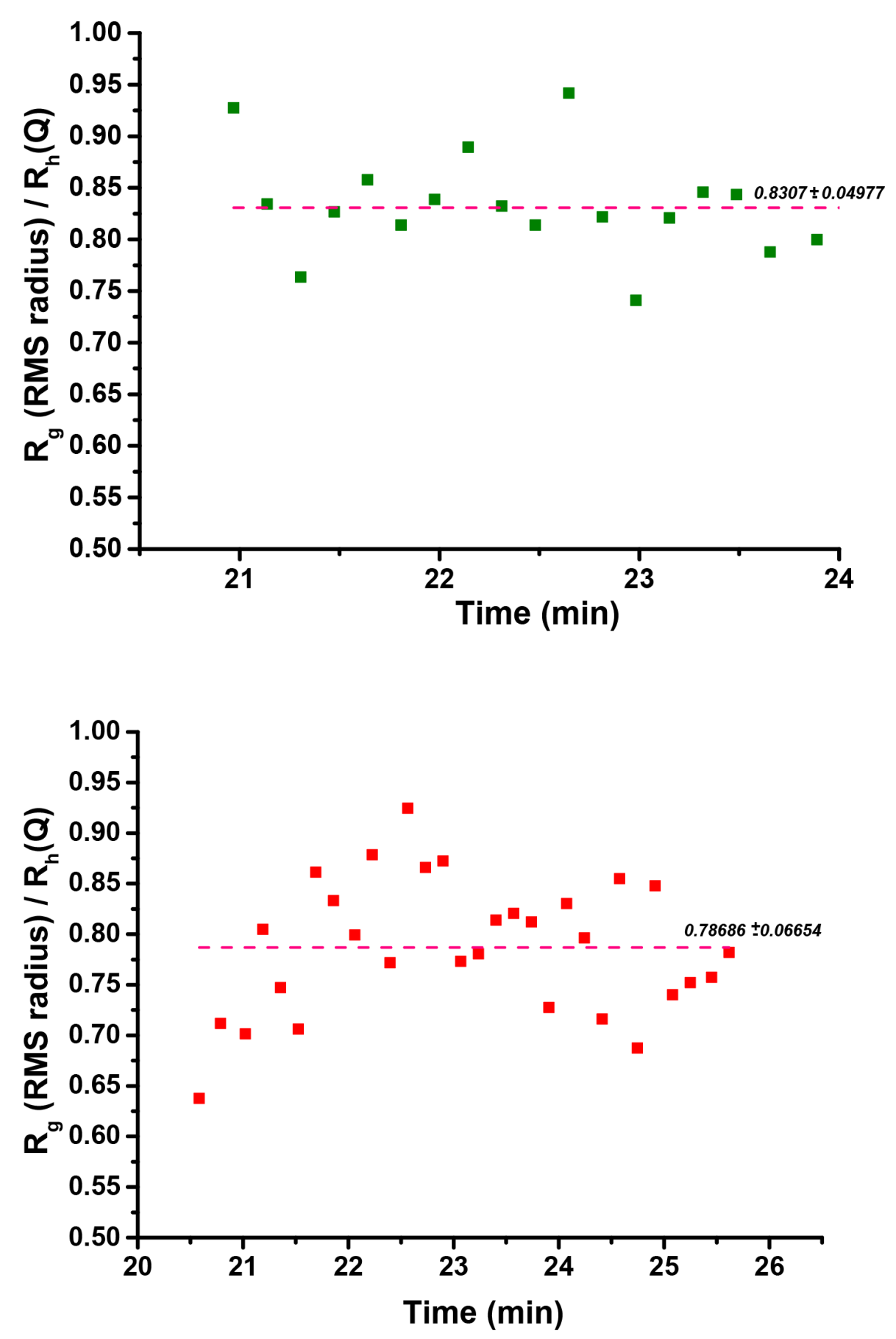

Supplementary Figure 5: (TOP) Radii of gyration (RMS) divided by the hydrodynamic radii $\left(\mathrm{R}_{\mathrm{h}}\right)$ over the entire size distribution peak of empty stomatocytes. (Bottom) Radii of gyration (RMS) divided by the hydrodynamic radii $\left(\mathrm{R}_{\mathrm{h}}\right)$ over the entire size distribution peak of catalase filled stomatocytes. The pink line in both graphs represents the mean value of these points. 

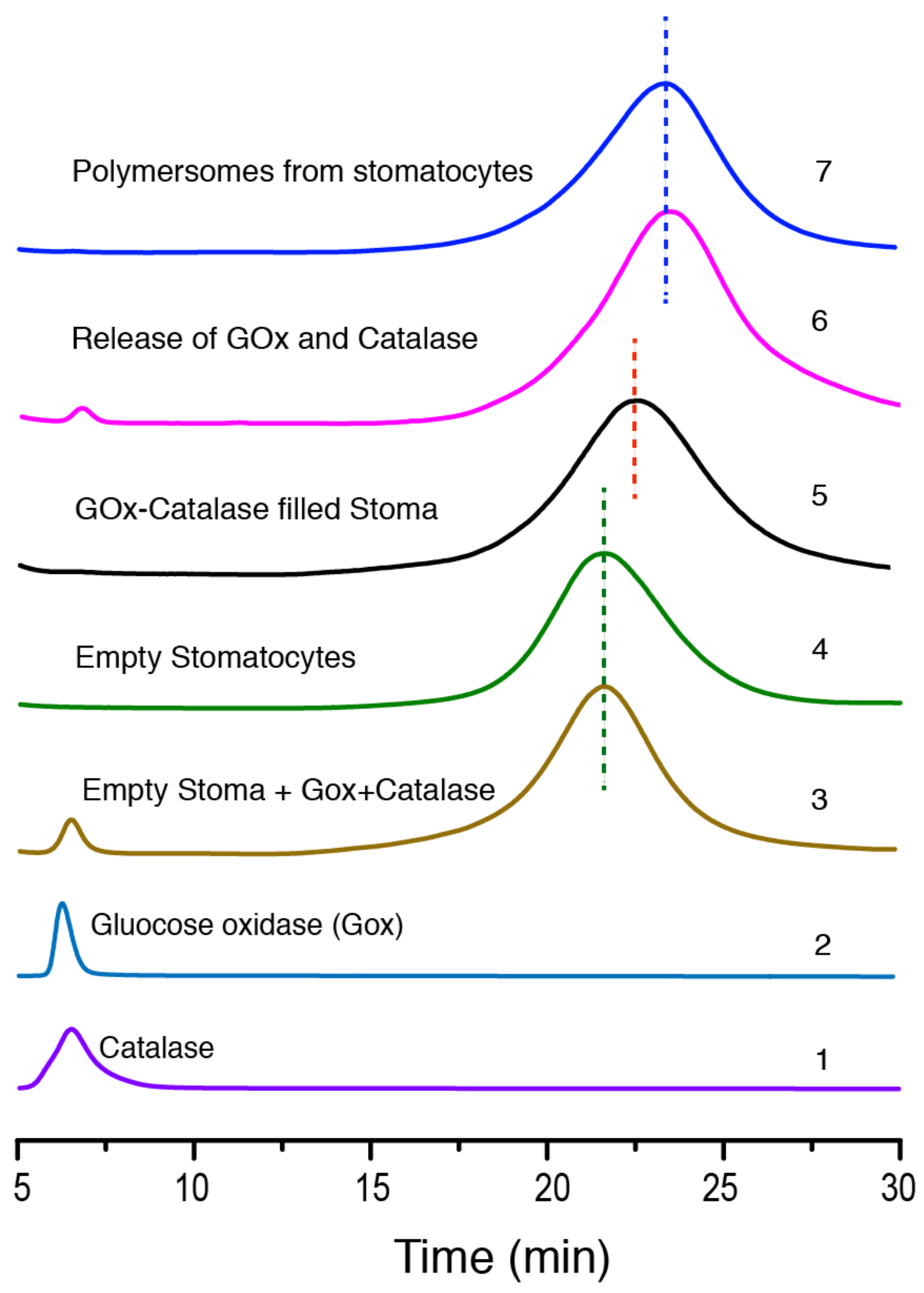

Supplementary Figure 6: Asymmetric field flow field fractionation (AFFF) chromatogram of 1- catalase enzyme, which was later encapsulated together with glucose oxidase (GOx) inside the cavity of the 
stomatocytes. 2- AFFF chromatogram of GOx enzyme, which was later encapsulated with catalase inside the stomatocytes. 3- AFFF chromatogram of catalase and GOx $(1: 3 \mathrm{w} / \mathrm{w})$, and stomatocytes mixed together, this experiment was done to check if the enzymes are adhering onto the surface of stomatocytes. The availability of both enzymes and their percentage amount was determined from the light scattering data (LS) by calculating their cumulative weight fraction for a dn/dc of 0.185 . The results confirmed the presence of almost the same ratio of catalase to GOx mixed with the stomatocytes, the enzyme did not adhere onto the surface of the stomatocytes as both catalase and the stomatocytes peaks were at exactly the same retention time as their controls (pure catalase and stomatocytes 1 and 4). 4- AFFF chromatogram of empty closed stomatocytes. 5- AFFF chromatogram of closed stomatocytes encapsulating catalase and GOx. Note the chromatogram of the filled stomatocytes shows a slight shift to a later retention times as observed previously in the case of catalase encapsulation (supplementary figure 5). 6- AFFF chromatogram of the release experiment where the filled stomatocytes were shape transformed into polymersomes. This led into release of the encapsulated enzymes and thus the retention of the enzymes peak.7- AFFF chromatogram of polymersomes obtained from empty closed stomatocytes. 

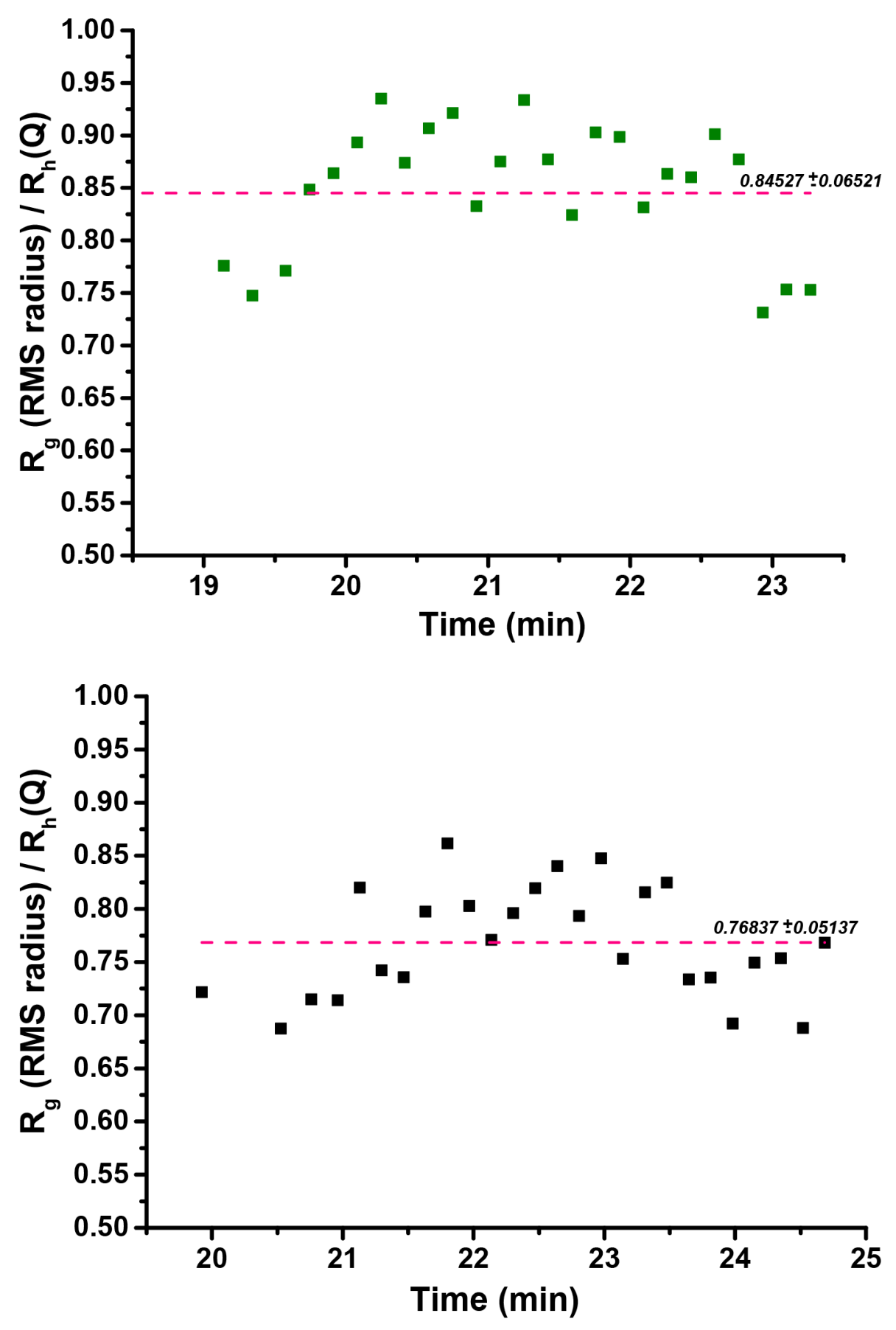

Supplementary Figure 7: (TOP) Radii of gyration (RMS) divided by the hydrodynamic radii $\left(\mathrm{R}_{\mathrm{h}}\right)$ over the entire size distribution peak of the empty stomatocytes (GOx-catalase experiment batch). (Bottom) Radii of gyration (RMS) divided by the hydrodynamic radii $\left(\mathrm{R}_{\mathrm{h}}\right)$ of the entire peak range of the GOxcatalase filled stomatocytes. The pink line in both graphs represents an average value of these points. 


\section{S3.2.2. EDX}
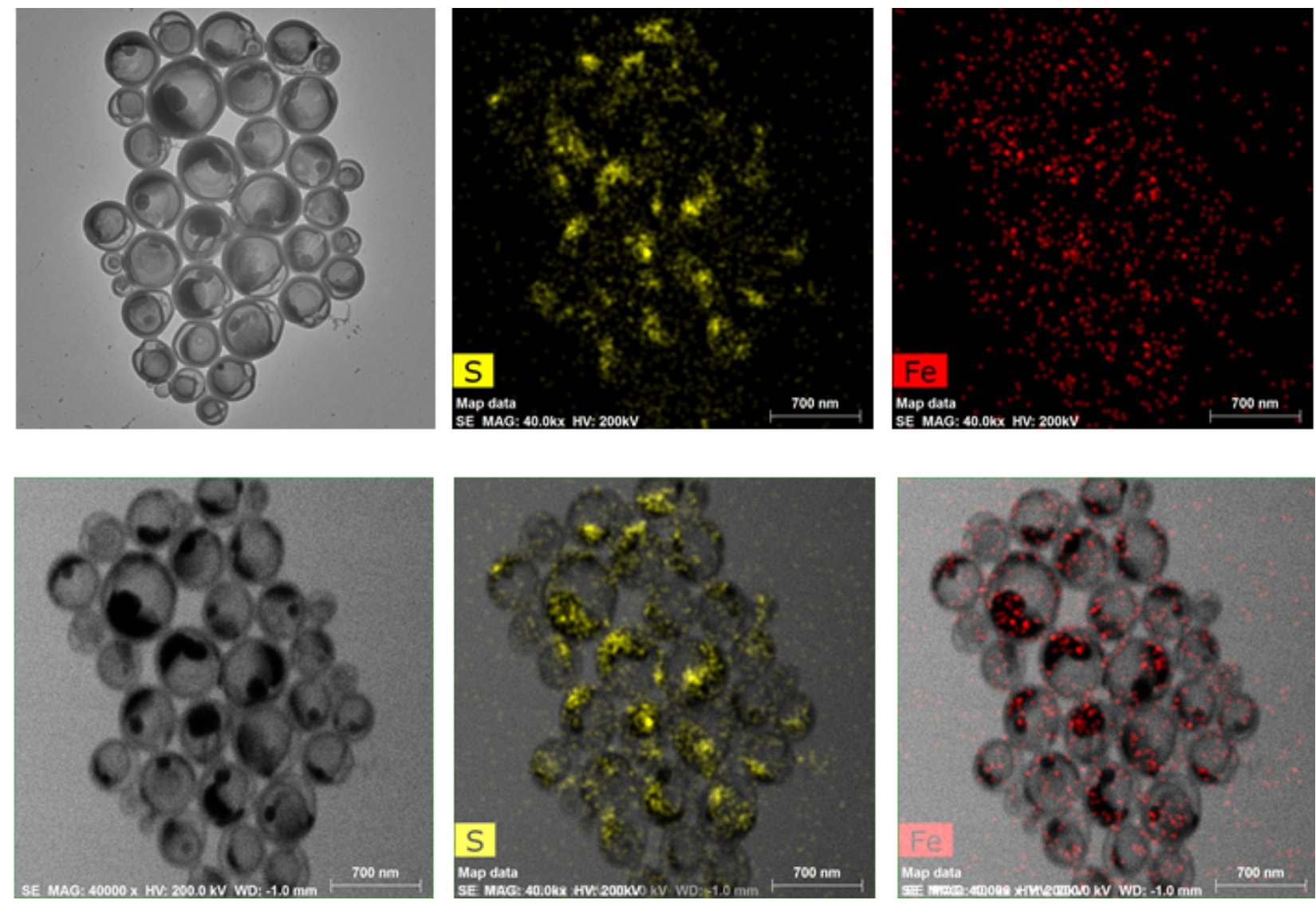

Supplementary Figure 8: TEM, secondary emission and Energy Dispersive X-ray (EDX) mapping of sulphur (S, Yellow) and Iron (Fe, red) in a group of catalase-filled stomatocytes to demonstrate the encapsulation of the enzyme containing both elements in their structure. The images were overlaid using Photoshop software to show the positioning of these elements in the stomach of stomatocytes. This technique was used earlier to show the positioning of several materials inside the polymersomes membrane..$^{5}$ 

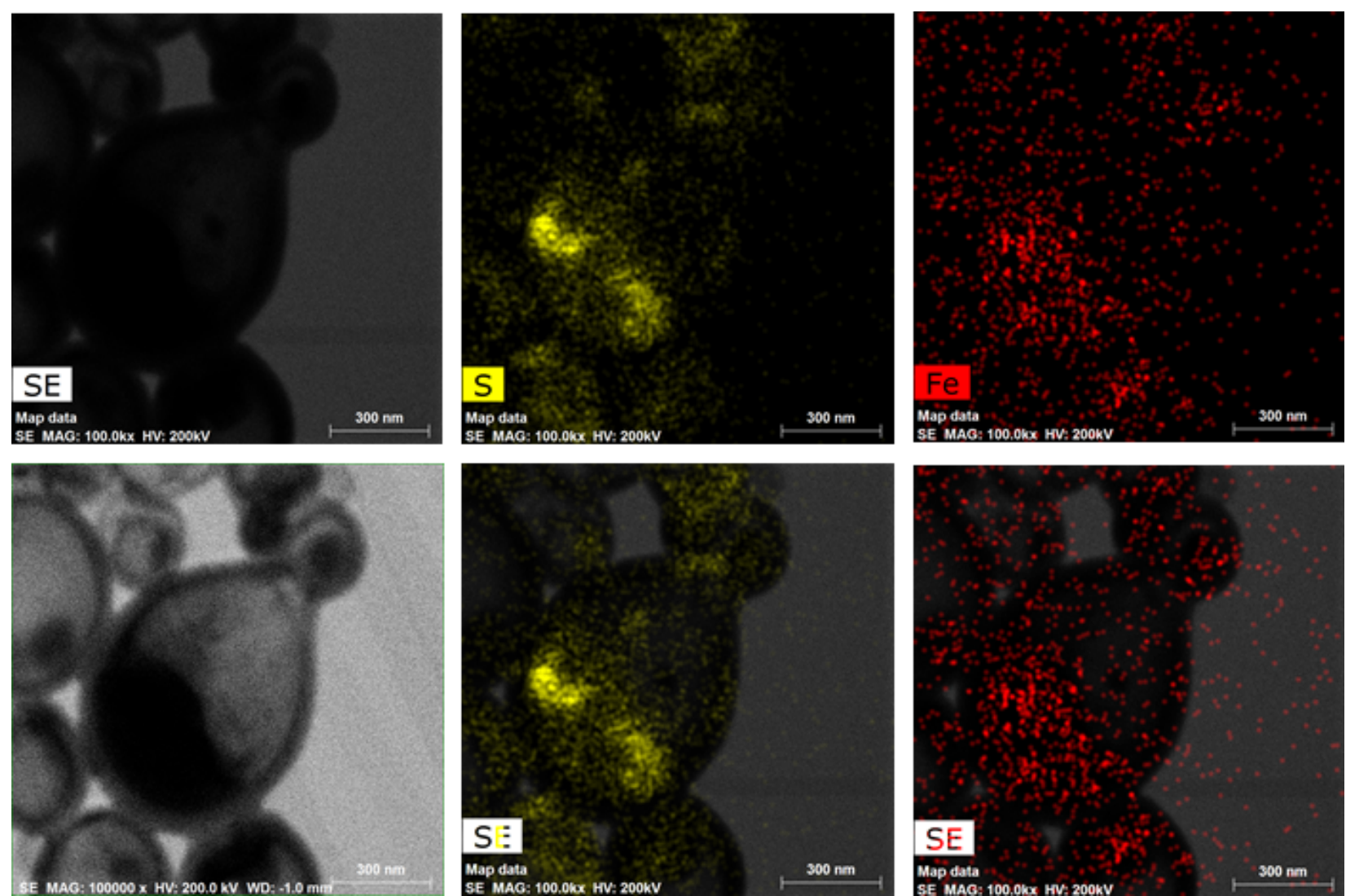

Supplementary Figure 9: TEM, secondary emission and Energy Dispersive X-ray (EDX) mapping of sulphur (S, Yellow) and Iron (Fe, red) in a single catalase-filled stomatocyte. Images were overlaid using Adobe Photoshop software to show the positioning of these elements in the inner compartment of the stomatocyte.
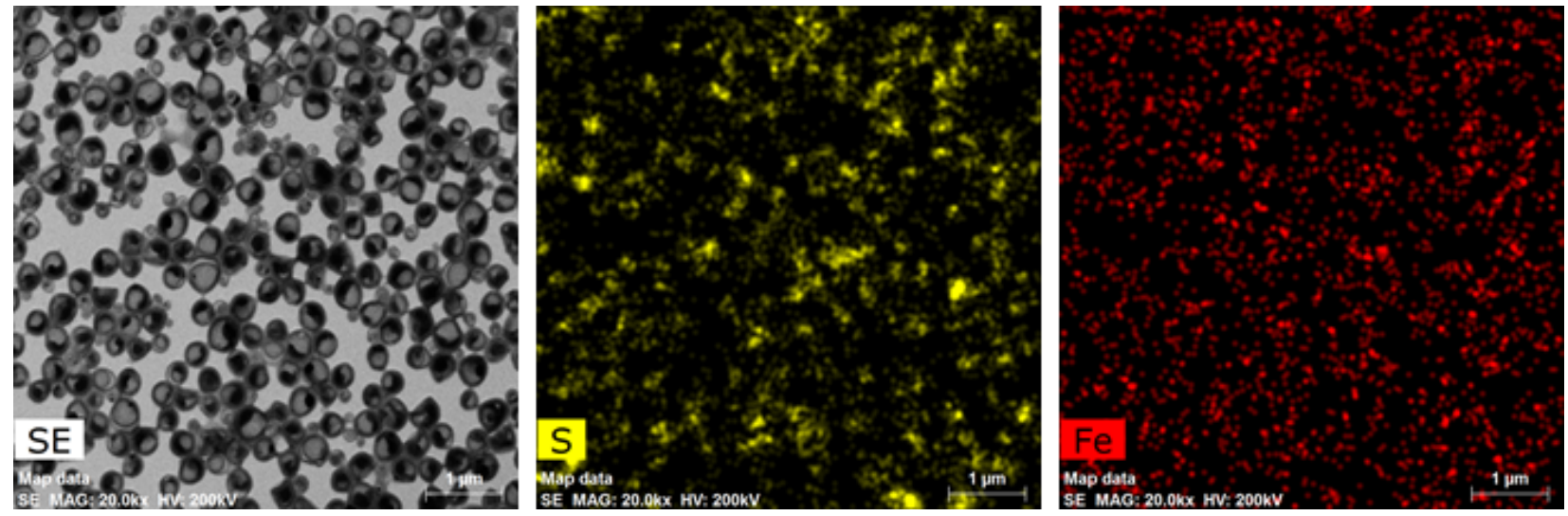
Supplementary Figure 10: TEM, secondary emission and Energy dispersive X-ray (EDX) mapping of sulphur (S, Yellow) and Iron (Fe, red) in a group of catalase-filled stomatocytes (low magnification image) to demonstrate the high encapsulation efficiency of the enzyme over a large number of structures.

\section{S3.3. Incorporation efficiency of enzymes in the stomatocytes determination}

\begin{tabular}{|l|l|l|l|l|}
\hline Encapsulated enzyme & $\begin{array}{l}\text { Enzyme } \\
\text { assayed }\end{array}$ & $\begin{array}{l}\text { Initial solution } \\
\text { activity (units } \\
\mathrm{mL}^{-1} \text { ) }\end{array}$ & $\begin{array}{l}\text { Incorporated } \\
\text { activity (units } \\
\mathrm{mL}^{-1} \text { ) }\end{array}$ & $\begin{array}{l}\text { \% incorporation } \\
\text { efficiency based on the } \\
\text { enzyme activity }\end{array}$ \\
\hline Catalase & Catalase & 21000 & $5125 \pm 261$ & $24.4 \pm 1.2$ \\
\hline $\begin{array}{l}\text { GOx/Catalase } \\
\text { (inhibited with sodium } \\
\text { azide) }\end{array}$ & GOx & 2739 & $890 \pm 47$ & $32.5 \pm 1.7$ \\
\hline GOx/Catalase & Catalase & 14000 & $3825 \pm 243$ & $27.3 \pm 1.7$ \\
\hline
\end{tabular}

Supplementary Table 3 Enzyme incorporation efficiency based on its activity: Activity of glucose oxidase and catalase -filled stomatocytes was determined by a coupled enzymatic reaction. In the catalase activity assay, catalase first reacts with $\mathrm{H}_{2} \mathrm{O}_{2}$ to produce water and oxygen $\left(\mathrm{O}_{2}\right)$. After an incubation period, Ampliflu ${ }^{\text {TM }}$ Red reagent reacts with unreacted $\mathrm{H}_{2} \mathrm{O}_{2}$ and HRP in a 1:1 stoichiometry to produce resorufin. As the catalase activity increases, the resorufin signal decreases.

A recovery of catalase from the nanoreactors was around $24 \%$ from the initial feed concentration of $12 \mathrm{mg} \mathrm{mL}^{-1}$ (total catalase concentration). When catalase and glucose oxidase were coencapsulated, a total enzyme recovery was found to be up to $30 \%$ from the total enzyme feed concentration (total enzyme concentration is $16 \mathrm{mg} \mathrm{mL}^{-1}$ ). This is significantly higher than statistical encapsulation and is possibly due to a templating effect, as found previously. ${ }^{6,7}$

For the activity of GOx, an assay using glucose, HRP and 10-Acetyl-3,7-dihydroxyphenoxazine (Ampliflu ${ }^{\mathrm{TM}}$ Red) was used. Glucose reacts with GOx to form D-gluconolactone and $\mathrm{H}_{2} \mathrm{O}_{2}$. In the presence of horseradish peroxidase (HRP), $\mathrm{H}_{2} \mathrm{O}_{2}$ reacts with Ampliflu ${ }^{\mathrm{TM}}$ Red in a 1:1 stoichiometry to 
generate red-fluorescent oxidation product, resorufin which has excitation and emission maxima at 571 $\mathrm{nm}$ and $585 \mathrm{~nm}$ respectively.

The enzymatic activities are expressed in units $\mathrm{mL}^{-1}\left(\mathrm{U} \mathrm{mL}^{-1}\right)$, where 1 unit of glucose oxidase oxidizes $1.0 \mu$ mole of glucose togluconolactone and $\mathrm{H}_{2} \mathrm{O}_{2}$ per minute in a solution saturated with oxygen at $\mathrm{pH} 5.1$ and $35^{\circ} \mathrm{C}$. One unit of catalase decomposes $1.0 \mu$ mole of $\mathrm{H}_{2} \mathrm{O}_{2}$ per minute at $\mathrm{pH} 7.0$ at $25^{\circ} \mathrm{C}$. Note that when GOx activity was measured in the stomatocytes, it was encapsulated with inactive catalase inhibited irreversibly by sodium azide and purified.

Stock solutions of $10 \mathrm{U} \mathrm{mL}^{-1}$ of GOx, $10 \mathrm{U} \mathrm{mL}^{-1}$ catalase, $10 \mathrm{U} \mathrm{mL}^{-1} \mathrm{HRP}, 20 \mathrm{mM}$ Ampliflu ${ }^{\mathrm{ru}}$ Red (DMSO), $500 \mu \mathrm{M} \mathrm{H}_{2} \mathrm{O}_{2}$ and $1 \mathrm{mM}$ D-glucose were freshly prepared before each series of measurements. All dilutions were made in $100 \mathrm{mM}$ potassium phosphate buffer, $\mathrm{pH} 7.0$ containing $1 \mathrm{mM} \mathrm{MgCl}{ }_{2}$ and 1 mM EDTA.

For catalase, the activity of the stomatocytes was determined using the interpolation of a $3^{\text {rd }}$ order polynomial fit across the catalase concentrations vs. fluorescence in the range between $0.1 \mathrm{U} \mathrm{mL}^{-1}$ and 0.4 $\mathrm{U} \mathrm{mL}^{-1}$.

$\left(y=-38,627,555.56 x^{3}+41,291,376.19 x^{2}-15,014,687.06 x+1,909,231.93, R^{2}=1.00\right)$

For GOx, a linear trend fit was used in measurements of solutions containing unknown amounts of enzyme to determine the amount of active enzyme present. For GOx, the relationship found was $y=$ 297.69x-5.26, $\mathrm{r}^{2}=0.99$ in the range of $0.1-0.35 \mathrm{U} \mathrm{mL}^{-1} \mathrm{GOx}$. 


\section{S3.2.4. Enzyme driven nanomotors tracking and analysis}
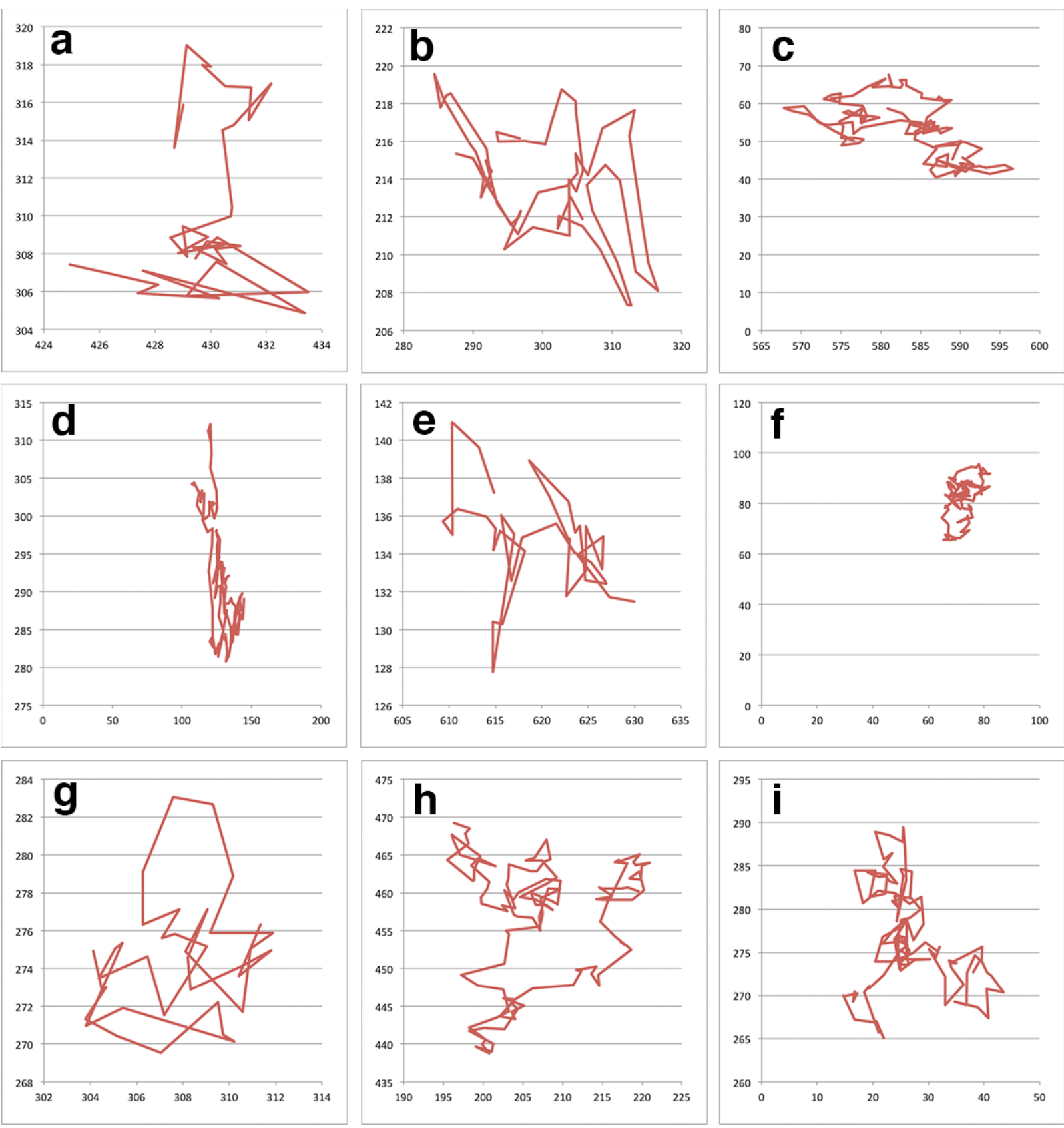

Supplementary Figure 11: (a-d) Sample trajectories of stomatocytes nanomotors before adding fuel. (ei) sample trajectories of EMPTY stomatocytes after adding fuel (hydrogen peroxide) or hydrogen peroxide). Please note that adding fuel did not affect the Brownian motion of the empty stomatocytes. 

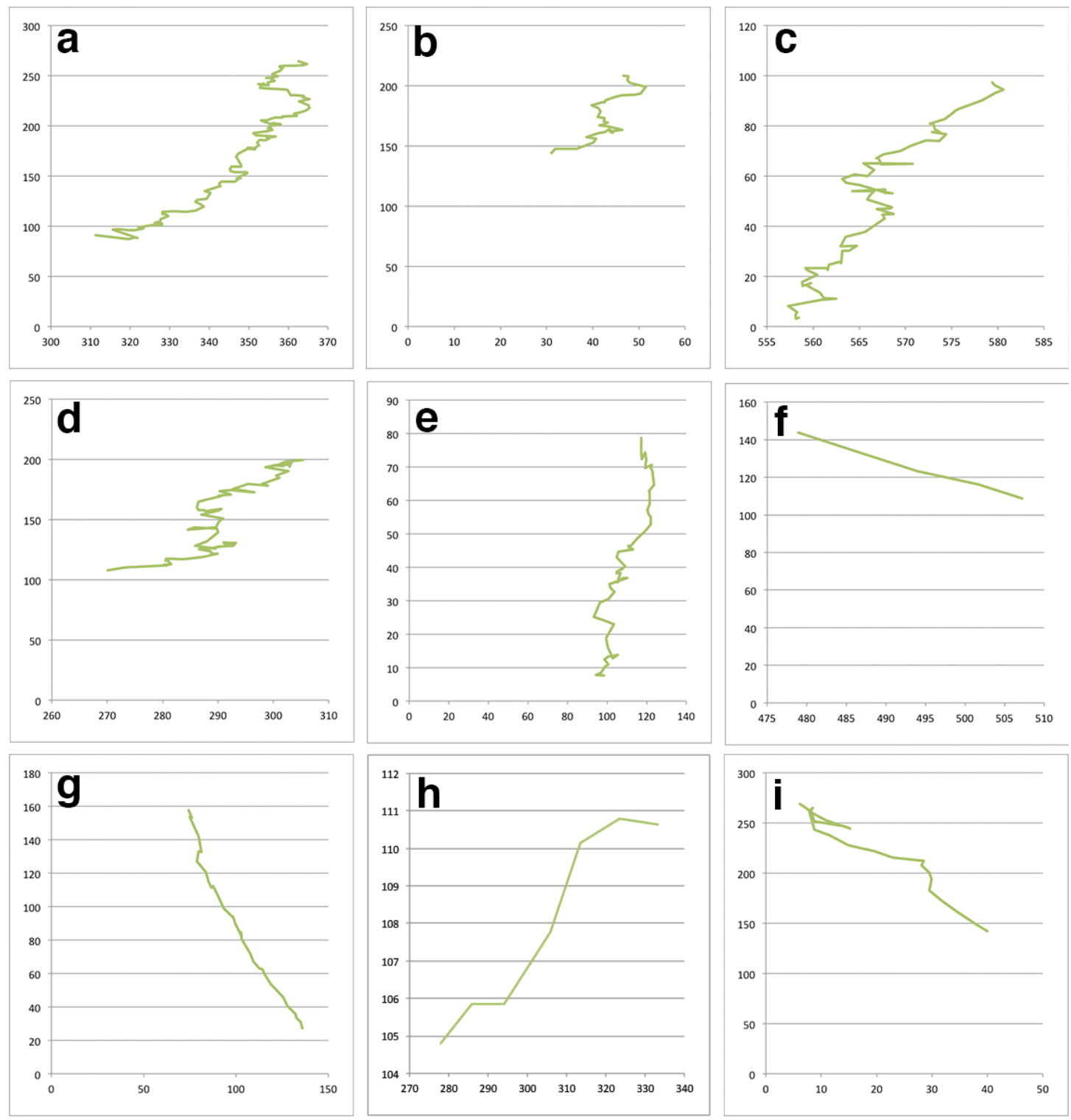

Supplementary Figure 12: Sample trajectories of stomatocytes nanomotors after adding fuel. (a-e) sample trajectories of stomatocytes nanomotors moving in low $\mathrm{H}_{2} \mathrm{O}_{2}$ concentration $(10 \mathrm{mM})$. (f-i) sample trajectories of stomatocytes motors moving in high $\mathrm{H}_{2} \mathrm{O}_{2}$ concentration $(150 \mathrm{mM})$. Please note the propulsive movement trajectories of the stomatocytes compared to those when in Brownian motion. 

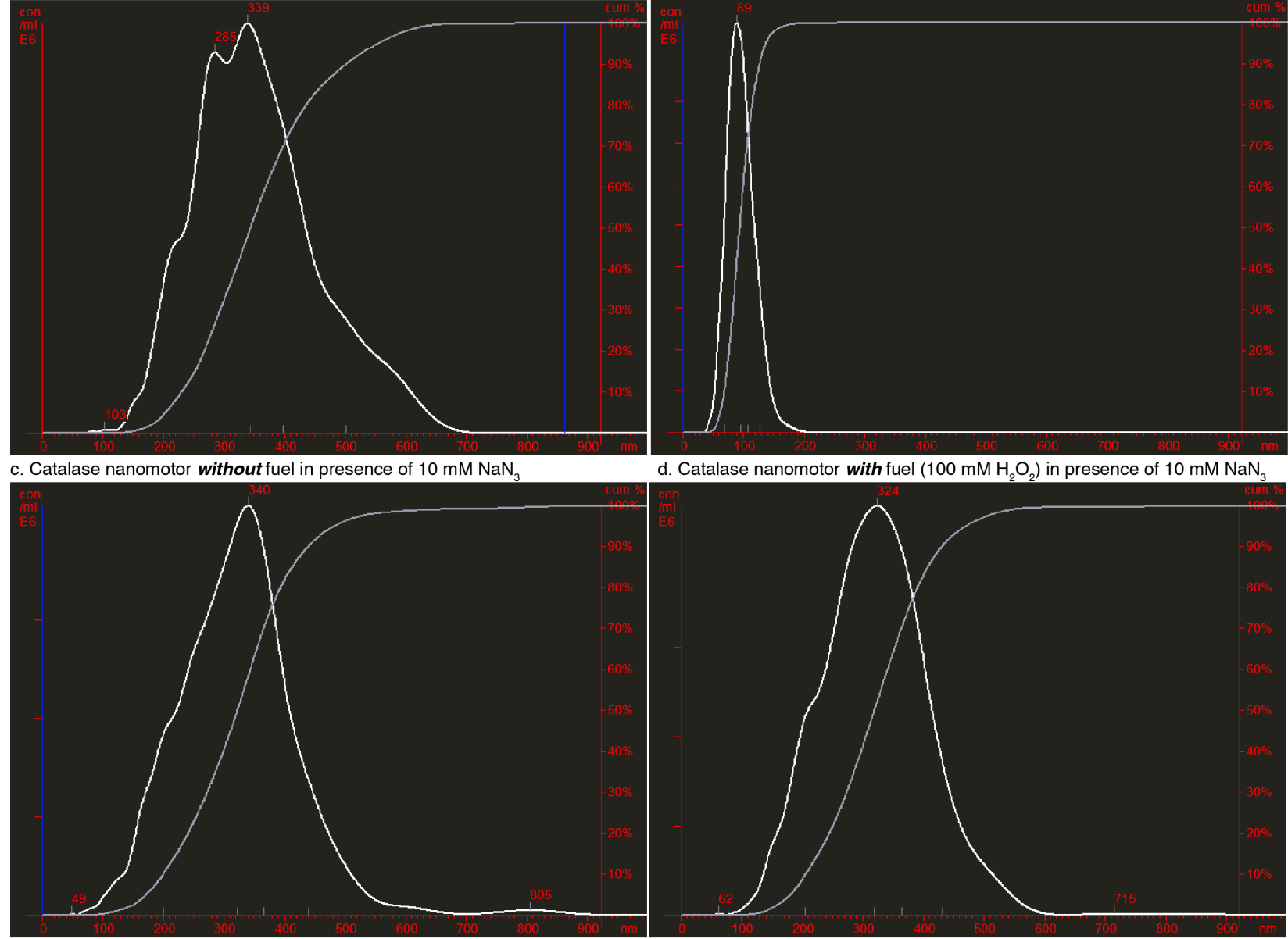

e. Catalase nanomotor with fuel $\left(100 \mathrm{mM} \mathrm{H}_{2} \mathrm{O}_{2}\right)$ in presence of trypsin

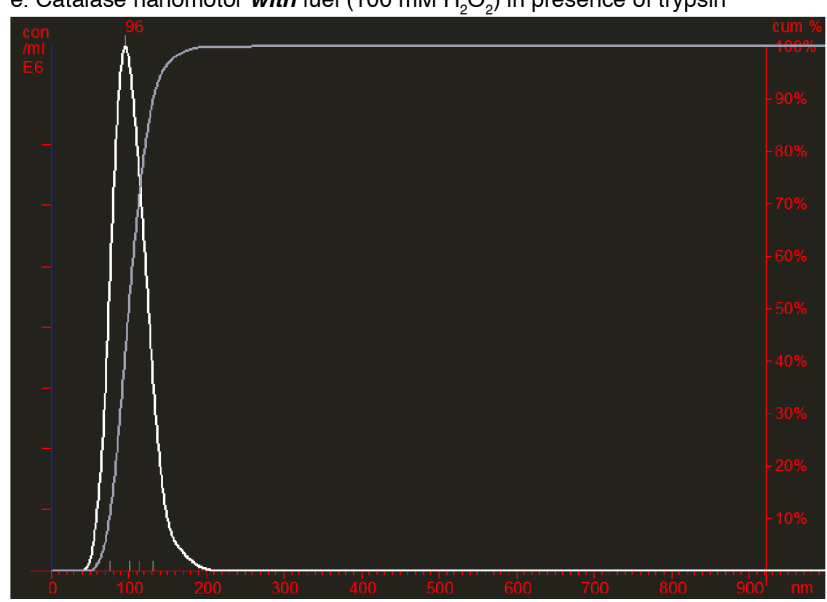

Supplementary Figure 13: Inhibition experiment The apparent sizes of the catalase nanomotors a. before and $\mathrm{b}$ after addition of $100 \mathrm{mM} \mathrm{H}_{2} \mathrm{O}_{2}$. The nanomotors are appearing smaller due to directional movement $\mathrm{c}$. The apparent sizes of the catalase nanomotors without fuel after addition of $10 \mathrm{mM} \mathrm{NaN}_{3}$; The size of the structures is not affected by addition of azide d. The apparent sizes of the catalase 
nanomotors in the presence of $100 \mathrm{mM} \mathrm{H}_{2} \mathrm{O}_{2}$ and $10 \mathrm{mM} \mathrm{NaN}_{3}$; The movement of the motors is inhibited due to inhibition of the catalase resulting in sizes of the nanomotors as before fuel addition. e. The apparent sizes of the catalase nanomotors in the presence of $100 \mathrm{mM} \mathrm{H}_{2} \mathrm{O}_{2}$ and $434 \mu \mathrm{M}$ trypsin. The movement of the motors is not inhibited after addition of trypsin.

\section{MSD fitting Cat Motor}

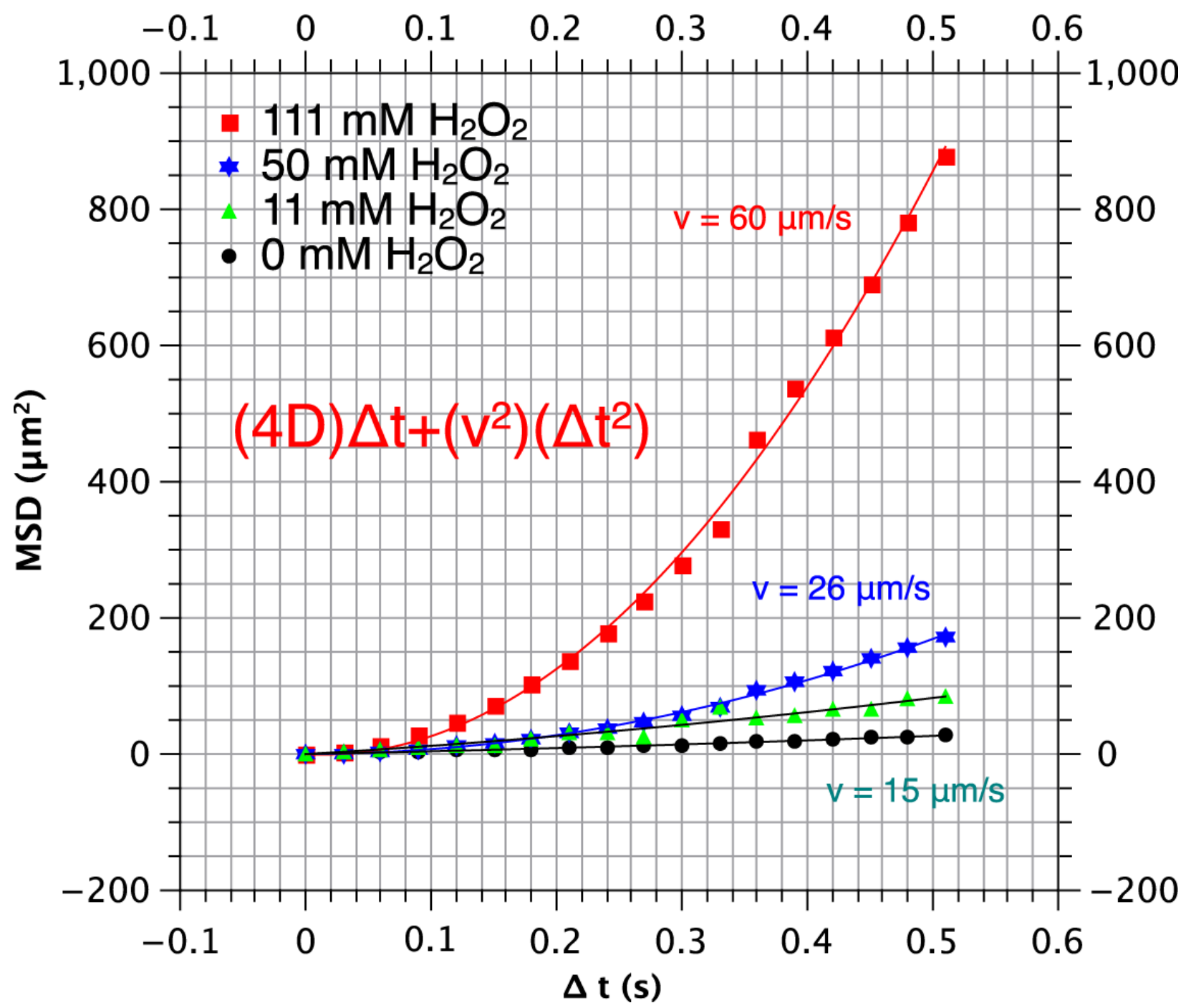

Supplementary Figure 14: Average MSD of the catalase-filled stomatocytes after the addition of fuel at different concentrations (11-111 $\left.\mathrm{mM} \mathrm{H}_{2} \mathrm{O}_{2}\right)$, calculated from the tracking coordinates of on average 105 particles. 


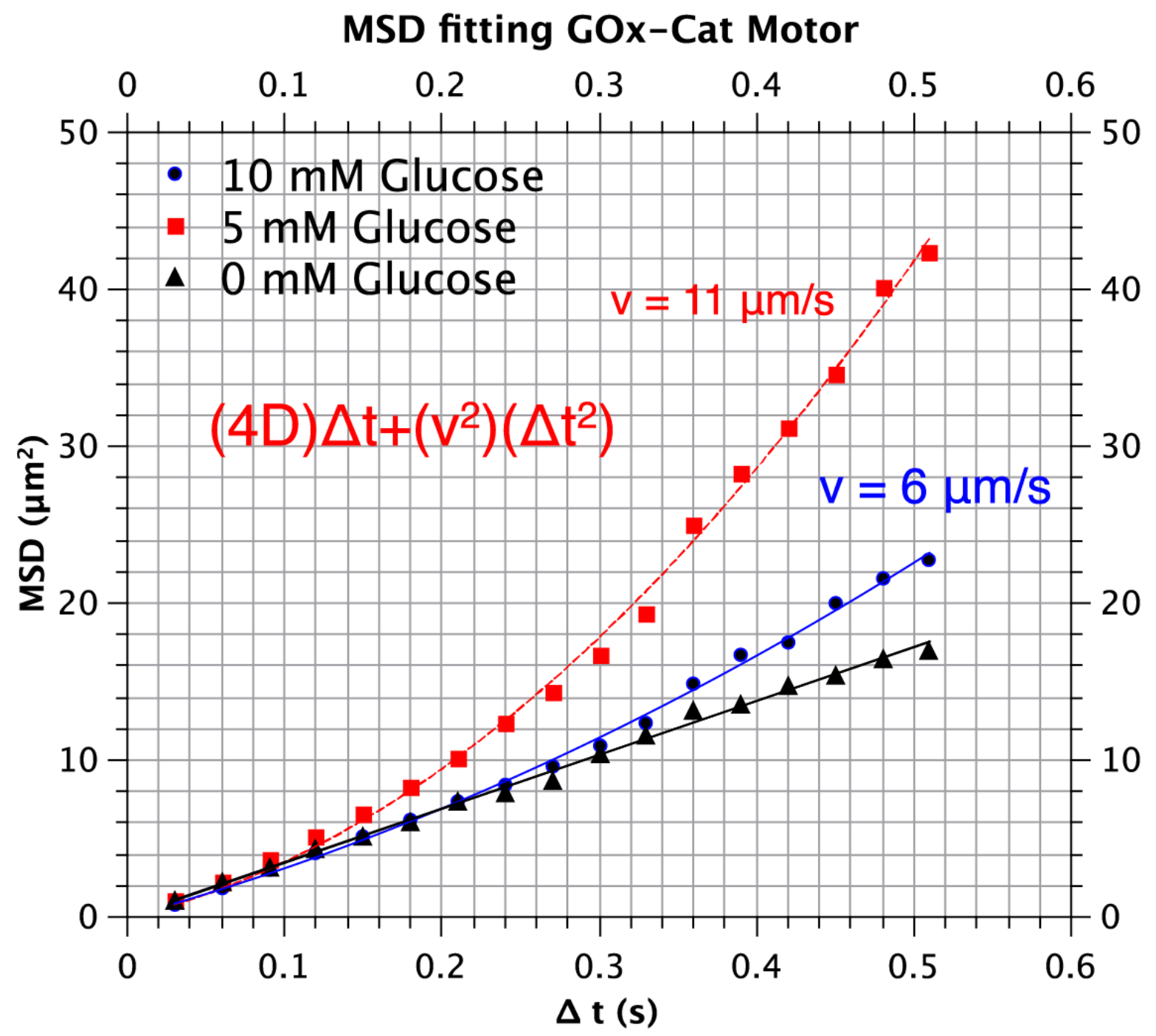

Supplementary Figure 15: Average MSD of the GOx-catalase two enzyme-driven nanomotors after the addition of fuel at different concentrations (5 and $10 \mathrm{mM}$ glucose), calculated from the tracking coordinates of on average 100 particles. 


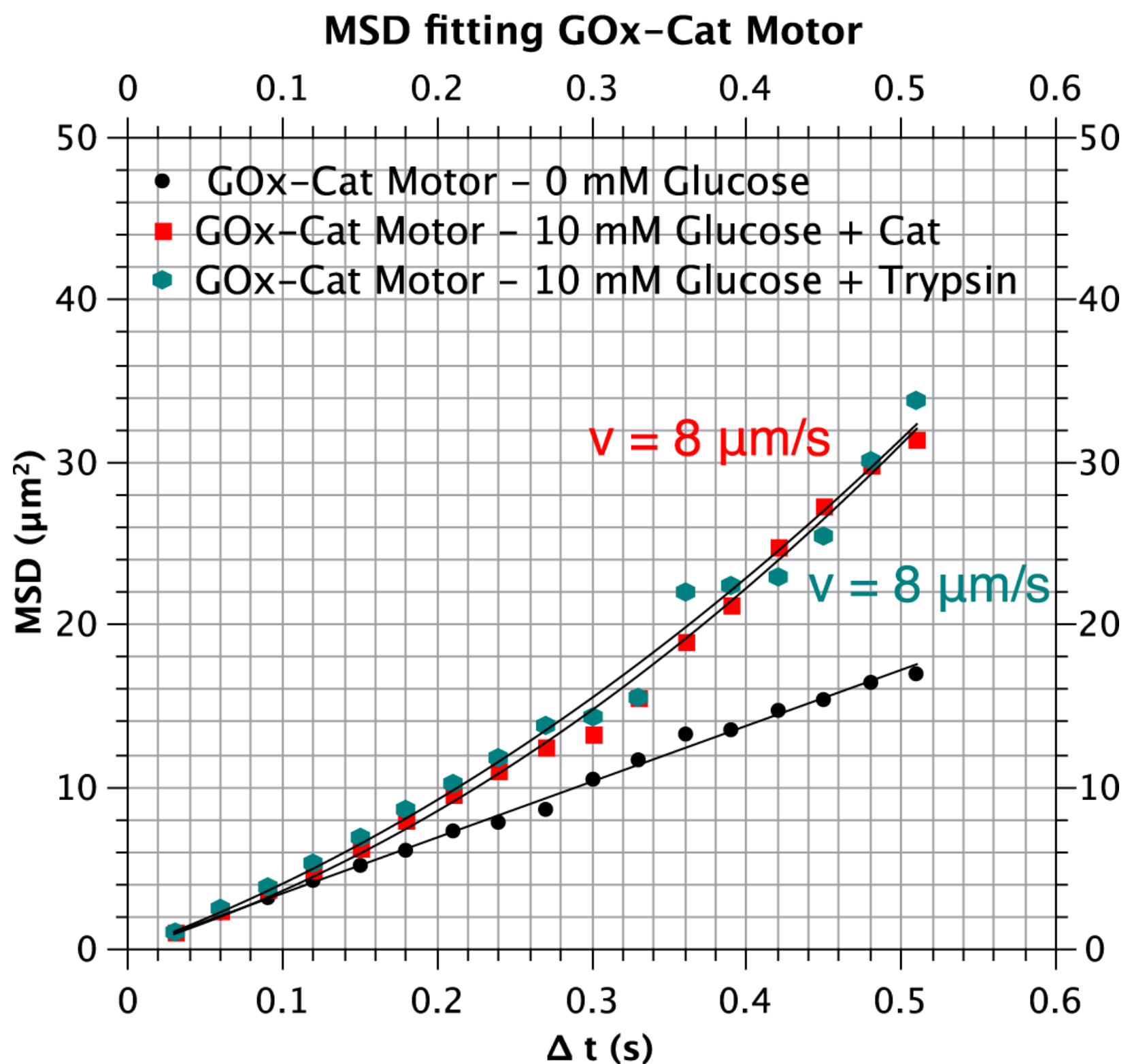

Supplementary Figure 16: Average MSD of the GOx-catalase two enzyme-driven nanomotors in the absence of glucose and after the addition of $10 \mathrm{mM}$ glucose and $230 \mu \mathrm{M}$ catalase (red squares) or $434 \mu \mathrm{M}$ trypsin (green diamond). 


\section{S4. References:}

1. Wilson, D. A.; Nolte, R. J. M.; van Hest, J. C. M. Autonomous Movement of PlatinumLoaded Stomatocytes. Nat. Chem. 2012, 4, 268-274.

2. Kim, K. T.; Cornelissen, J. J. L. M.; Nolte, R. J. M.; van Hest, J. C. M. A Polymersome Nanoreactor with Controllable Permeability Induced by Stimuli-Responsive Block Copolymers. Adv. Mater. 2009, 21, 2787-2791.

3. van Rhee, P. G.; Rikken, R. S. M.; Abdelmohsen, L. K. E. A.; Maan, J. C.; Nolte, R. J. M.; van Hest, J. C. M.; Christianen, P. C. M.; Wilson, D. A. Polymersome Magneto-Valves for Reversible Capture and Release of Nanoparticles. Nat. Commun. 2014, 5.

4. Meeuwissen, S. A.; Kim, K. T.; Chen, Y.; Pochan, D. J.; van Hest, J. C. M. Controlled Shape Transformation of Polymersome Stomatocytes. Angew Chem., Int. Ed. 2011, 50, 7070-7073.

5. van Oers, M. C. M.; Abdelmohsen, L. K. E. A.; Rutjes, F. P. J. T.; van Hest, J. C. M. Aqueous Asymmetric Cyclopropanation Reactions in Polymersome Membranes. Chem. Commun. 2014, 50, 4040-4043.

6. Peters, R. J. R. W.; Marguet, M.; Marais, S.; Fraaije, M. W.; van Hest, J. C. M.; Lecommandoux, S. Cascade Reactions in Multicompartmentalized Polymersomes. Angew Chem., Int. Ed. 2014, 53, 146-150.

7. Baumann, P.; Balasubramanian, V.; Onaca-Fischer, O.; Sienkiewicz, A.; Palivan, C. G. LightResponsive Polymer Nanoreactors: A Source of Reactive Oxygen Species on Demand. Nanoscale 2013, 5, 217-224. 